DOI: $\underline{\text { https://doi.org/10.31933/jemsi.v3i2 }}$

Received: 12 Oktober 2021, Revised: 15 November 2021, Publish: 6 Desember 2021

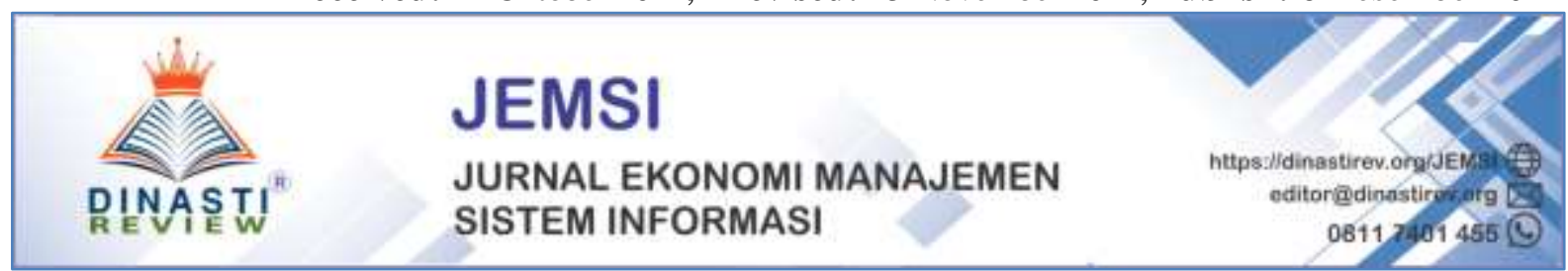

\title{
UPAYA MENINGKATKANPENDAPATAN MELALUI JUAL BELI ONLINE DIMASA PANDEMI COVID-19 (STUDI KASUS PADA TOKO BAJU AFA COLLECTION KELURAHAN SUNGAI LOKAN KECAMATAN SADU)
}

\author{
Siti Sarina ${ }^{1}$, Zaenal Abidin ${ }^{2}$, Khusnul Yatima ${ }^{3}$ \\ ${ }^{1)}$ Sekolah Tinggi Ilmu Ekonomi Syari’ah Al-Mujaddid Tanjung Jabung Timur, \\ sitisarina603@gmail.com \\ ${ }^{2)}$ Sekolah Tinggi Ilmu Ekonomi Syari'ah Al-Mujaddid Tanjung Jabung Timur, \\ zaabiangsui@gmail.com \\ ${ }^{3)}$ Sekolah Tinggi Ilmu Ekonomi Syari'ah Al-Mujaddid Tanjung Jabung Timur, \\ yatimakhusnul@yahoo.co.id
}

Korespondensi Penulis: Siti Sarina

\begin{abstract}
Abstrak: Penelitian ini berjudul "Upaya meningkatkan Pendapatan melalui Jual Beli Online di masa Pandemi Covid-19 (Studi Kasus pada Toko Baju Afa Collection). Adapun tujuan penelitian ini adalah untuk menganalisa Upaya-upaya yang dilakukan oleh Toko Baju Afa Collektion dalam meningkatkan pendapatan di tengah Pandemi Covid-19 ini, karena sebagaimana yang kita ketahui salah satu dampak yang diakibatkan oleh pandemi ini yaitu pasar yang menjadi sepi sehingga membuat banyak pengusaha dan perusahaan harus berhenti beroperasi. Sementara kebutuhan hidup tidak bisa berhenti untuk dipenuhi dan semakin semakin meningkat, oleh sebab itu dibutuhkan upaya dan strategi yang tepat dalam melakukan penjualan pada Toko Baju Afa Collektio di Kelurahan Sungai Lokan Kecamatan Sadu. pada penelitian ini penulis menggunakan metode Kualitatif dengan tekhnik triangulasi yaitu penggabungan dari Observasi, Wawancara dan Dokumentasi guna mendapatkan data yang akurat. Data yang digunakan pada penelitian ini yaitu data primer yaitu data yang bersumber langsung dari pelaku usaha, karyawan dan konsumen Toko Afa Collektion. Sementara data sekundernya yaitu dokumentasi-dokumentasi kegiatan Afa Collektion dalam menjalankan usahanyapada masa pandemi Covid-19 ini di Kelurahan Sungai Lokan Kecamatan Sadu. menyediakan barangnya secara langsung dimana system pembeliannyapun dengan system packing order (pesan baru dipaketkan).
\end{abstract}

Kata Kunci: Upaya, Pendapatan, Jual Beli Online, Pandemi Covid-19

\section{PENDAHULUAN}

Kecamatan Sadu merupakan salah satu wilayah yang terdapat di Kabupaten Tanjung Jabung Timur Provinsi Jambi dimana mayoritas penduduknya adalah nelayan, dan sebagian yang lain juga berpropesi sebagai petani, peternak, wirausaha dan karyawan di beberapa lembaga pemerintah dan lembaga sewasta. Kecamatan sadu merupakan salah satu daerah yang ikut merasakan dampak dari penyebaran wabah Covid-19 sehingga banyak mengalami 
perubahan baik pola kehidupan sehari-hari hingga perekonomian masyarakat yang mengalami penurunan. Hal ini dikarenakan Kecamatan Sadu sangat bergantung terhadap daerah lain untuk meningkatkan perekonomian, meskipun pada dasarnya kecamatan sadu juga memiliki tatanan pemerintahan sendiri sebagai salah satu Kecamatan di Kabupaten Tanjung Jabung Timur Provinsi Jambi.

Pada dasarnya menggunakan Jual Beli Online sebagai salah satu solusi dalam mengatasi kendala untuk meningkatkan pendapatan di tengah pandemi Covid-19 ini adalah pilihan yang sangat tepat, namun hal tersebut tidak akan maksimal jika tanpa adanya Upayaupaya yang dilakukan oleh pemilik Afa Collection dalam meningkatkan penghasilannya. Karena untuk menarik minat konsumen dibutuhkan strategi bisnis dan upaya yang tepat terlebih dalam menjalankan jual beli online yang pada dasarnya banyak dilakukan oleh banyak wirausaha lainnya, hal ini lah yang mendasari penulis untuk mengangkat judul proposal skripsi ini tentang "Upaya Meningkatkan Pendapatan melalui Jual Beli Online di masa Pandemi Covid-19 (Studi Kasus pada Toko Baju Afa Collection Kelurahan Sungai Lokan Kecamatan Sadu).

\section{TINJAUAN PUSTAKA}

Kajian tentang Upaya Meningkatkan Pendapatan melalui Jual Beli Online di masa Pandemi Covid-19 (Studi Kasus pada Toko Baju Afa Collection Kelurahan Sungai lokan Kecamatan Sadu) juga telah dilakukan oleh beberapa peneliti lainnya. Salah satunya yaitu diantaranya penelitian yang dilakukan oleh:

- Nur Khuzaimah Mahasiswi Institute Agama Islam Negeri Metro Jurusan Ekonomi Syariah Tahun Akademik 2019 yang meneliti tentang Jual Beli Online dengan Dropshipping Perspektif Fiqih Muamalah (Studi kasus mahasiswa jurusan ekonomi syariah angkatan 2015 IAIN Metro, Penelitian ini termasuk dalam penelitian jenis lapangan atau field reserce dengan sifat kualitatif adapun sumber data dalam penelitian ini diperoleh melalui metode wawancara (interview) terhadap penjual maupun pembeli online dengan sistem dropshipping, dan dokumentasi yang berupa data-data mahasiswa yang dibutuhkan dalam skripsi ini. Data yang terkumpul dianalisis menggunakan metode deskriptif yaitu menganalisis data yang dilakukan dengan jalan mendeskripsikan data dengan penelaran data yang logis.Berdasarkan hasil penelitian dapat disimpulkan bahwa sistem jual beli online dengan dropshipping yang telah dilakukan oleh mahasiswa Jurusan Ekonomi Syariah angkatan 2015 tidak dilarang dalam islam dan dapat dijalankan dengan menggunakan akad salam. Penggunaan akad salam diperbolehkan dalam sistem transaksi jual beli dropshipping selama memenuhi syarat akad salam.

- Dwi Rani Ambarwati Mahasiswi Universitas Islam Negeri Sumatera Utara Fakultas Ekonomi dan Bisnis Tahun Akademik 2019 yang meneliti tentang Analisis Jual Beli Online dengan menggunakan system Dropshipping dalam kajian Ekonomi Islam (Studi kasus dropshipper Shoppe mahasiswa UIN SU), penelitian ini menggunakan .Penelitian yang dilakukan ini berjenis penelitian kualitatif dengan bentuk deskriptif dan subyek yang di jadikan sumber dalam penelitian ini adalah Mahasiswa UIN SU yang berjualan online dengan menggunakan sistem dropshipping dan memakai aplikasi Shopee dengan sistem 
dropship yang tawarkan aplikasi tersebut yang terdiri dari 8 informan. Pengambilan data pada penelitian ini menggunakan teknik wawancara yang bersifat in-depth interview (wawancara mendalam). Hasil penelitian menunjukkan bahwa mekanisme jual beli online dengan menggunakan sistem dropshipping yang dilakukan dropshipper Shopee Mahasiswa UIN SU adalah membuat akun Shopee terlebih dahulu, mempromosikan barang dari supplierShopee, memilih \& membeli barang pada supplier Shopee jika ada konsumen yang memesan, isi alamat pembeli dengan lengkap, pilih metode pembayaran, centang tulisan "kirim sebagai dropshipper" lalu isi nama \& nomor telepon dropshipper pada kolom yang tertera dan klik kolom buat pesanan. Selanjutnya kajian Ekonomi Islam tentang jual beli online dengan sistem dropshipping yang dilakukan oleh dropshipper Shopee Mahasiswa UIN SU menunjukkan bahwa jual beli ini tidak sejalan dengan konsep bai' as-salam khususnya salam paralel \& prinsip/nilai dasar etika berbisnis dalam ekonomi Islam dimana terdapat unsur ketidakjelasan terhadap barang yang dijual dropshipperShopee, karena dropshipper tidak memiliki, mengetahui maupun melihat wujud asli barang secara nyata. Kemudian tidak ada unsur kejujuran (keterbukaan) oleh pihak dropshipper kepada pihak pembeli terkait sistem yang digunakan, selanjutnya terdapat unsur ketidakadilan didalamnya, karena dapat menimbulkan kerugian pada salah satu pihak yaitu pembeli.

- Irsyad Andriyanto mahasiswa Institute Agama Islam Negeri Kudus Tahun Akademik 2016 yang meneliti tentang Penguatan Daya Saing Usaha Mikro Kecil melalui e-Commerse, dimana pada penelitian ini penulis menggunakan metode Kualitatif dengan Tekhnis Triangulasi yaitu tekhnik gabungan dari Observasi, Wawancara dan Dokumentasi dalam mencari keabsahan data. Berdasarkan hasil penelitian ditemukan bahwa dalam pemanfaatan IT dalam bentuk e-Commerse yang dilakukan di UMKM di Desa Panduren memberikan dampak terhadap pelaku usaha, adapun dampak yang dirasakan yaitu (1) Pemasaran yang semakin meluas, (2) Menghemat Biaya (3) Menambah Relasi (4) Kemudahan dalam bertransaski (5) menamah penghasilan.

\section{KAJIAN TEORI}

Adapun yang menjadi landasan teori pada penelitian tentang Upaya Meningkatkan Pendapatan melalui Jual Beli Online di masa Pandemi Covid-19 (Studi Kasus pada Toko Baju Afa Collection Kelurahan Sungai lokan Kecamatan Sadu) yaitu:

\section{Jual Beli Online}

Kegiatan jual beli online saat ini semakin marak, apalagi situs yang digunakan untuk melakukan transaksi jual beli online ini semakin baik dan beragam. Namun, seperti yang kita ketahui bahwa dalam sistem jual beli online produk yang ditawarkan hanya berupa penjelasan spesifikasi barang dan gambar yang tidak bisa dijamin kebenarannya. Untuk itu sebagai pembeli, maka sangat penting untuk mencari tahu kebenaran apakah barang yang ingin dibeli itu sudah sesuai atau tidak. Menurut Kamus Besar Bahasa Indonesia, jual beli adalah persetujuan saling mengikat antara penjual, yakni pihak yang menyerahkan barang, dan pembeli sebagai pihak yang membayar harga barang yang dijual. Menurut Rahmat Syafe'i, secara bahasa jual beli adalah pertukaran sesuatu dengan sesuatu yang lain. 


\section{- Pedagang}

Pedagang adalah mereka yang melakukan perbuatan perniagaan (perdagangan) sebagai pekerjaannya sehari-hari, Pedagang kaki lima merupakan pedagang atau orang yang melakukan kegiatan atau usaha kecil tanpa didasari atas ijin dan menempati pinggiran jalan (trotoar) untuk menggelar dagangan. Menurut Evens dan Korff definisi pedagang kaki lima adalah bagian dan sektor informal kota yang yang mengebangkan aktivitas produksi barang dan jasa di luar kontrol pemerintah dan tidak terdaftar, banyak penjelasan yang dapat ditemui jika membahas mengenai PKL. Keberadaan PKL disini sangat menarik untuk dibahas satu persatu, misalnya mengenai dampak atas keberadaan PKL maupun mengenai cara pemerintah untuk menata PKL tersebut.

\section{- Pendapatan}

Pendapatan merupakan suatu hasil yang diterima oleh seseorang atau rumah tangga dariberusaha ataubekerja.Jenis masyarakat bermacam ragam, seperti bertani, nelayan, beternak, buruh, serta berdagang dan juga bekerja pada sektor pemerintah dan swasta. Pada konsep ekonomi, menurut Adam Smith penghasilan adalah jumlah yang dapat dikonsumsi tanpa harus mengakibatkan penurunan modal, termasuk modal tetap (fixed capital) dan modal berputar (circulatingcapital). Hicks mengatakan bahwa penghasilan adalah jumlah yang dikonsumsi oleh seseorang selama jangka waktu tertentu. Sementara itu, Henry Csimon yang memandang dari sudut penghasilan perorangan, mendefenisikan penghasilan sebagai jumlah dari nilai pasar barang dan jasa yang dikonsumsi dan perubahan nilai kekayaan yang ada pada awal dan akhir satu periode.

\section{- Pandemi Covid-19}

World Health Organization (WHO) menetapkan tentang virus corona atau yang biasa disebut dengan COVID-19 yang menjadi pandemi karena virus ini telah menyebar keberbagai negara bahkan sudah mendunia. WHO mengartikan pandemi sebagai suatu kondisi populasi pada dunia dan berpotensi menjadikan jatuh dan sakit. Pandemi sendiri adalah wabah yang berjangkit secara bersamaan yang menyebar luas. Pandemi COVID19 ini juga berdampak dari berbagai sektor kehidupan seperti ekonomi, sosial dan juga pendidikan.

\section{METODE PENELITIAN}

\section{Pendekatan dan Prosedur Penelitian}

Untuk mendapatkan data yang relevan dalam meneliti tentang Upaya Meningkatkan Pendapatan melalui Jual Beli Online di masa Pandemi Covid-19 (Studi Kasus pada Toko Baju Afa Collection Kelurahan Sungai lokan Kecamatan Sadu) ini, saya menggunakan metodologi kualitatif yaitu jenis penelitian yang temuan-temuannya tidak diperoleh melalui prosedur statistik atau bentuk hitungan lainnya. Selanjutnya dipilihnya penelitian kualitatif karena kemantapan peneliti berdasarkan pengalaman penelitiannya dan metode kualitatif dapat memberikan perincian yang lebih kompleks tentang fenomena yang sulit diungkapkan oleh metode kuantitatif. Proses penelitian kualitatif ditujukan untuk menghasilkan temuan yang benar-benar bermanfaat sehingga memerlukan perhatian yang serius terhadap berbagai hal 
yang dipandang perlu, dalam membahas proses penelitian kualitatif ada tiga hal yang perlu diperhatian yaitu kedudukan teori, metodologi penelitian dan desain penelitian kualitatif. ${ }^{1}$ Penelitian Kualitatif adalah deskriptif, daya yang dikumpulkan lebih mengambil bentuk katakata atau gambar dari pada angka-angka..

\section{Desain Penelitian}

penelitian ini mencocokkan antara realita empiris dengan teori yang berlaku dengan menggunakan metode deskriptif, Menurut Keirl dan Miller yang dimaksud dengan penelitian kualitatif adalah "tradisi tertentu dalam ilmu pengetahuan sosial yang secara fundamental bergantung pada pengamatan, manusia, kawasannya sendiri, dan berhubungan dengan orangorang tersebut dalam bahasanya dan peristilahannya".

\section{Partisipasi Pengumpulan Data}

Lokasi Penelitian ini bertempat di Kelurahan Sungai Lokan Kecamatan Sadu, Lokasi ini dipilih karena Toko Baju Afa Collection ini merupakan suatu toko baju yang ada di Kelurahan Sungai Lokan Kecamatan Sadu dan lokasi yang mudah dijangkau oleh penulis.

\section{Prosedur Pengumpulan Data}

Tehnik pengumpulan data merupakan langkah yang paling strategis dalam penelitian, karena tujuan utama dalam penelitian adalah mendapatkan data. Tanpa mengetahui tehnis pengumpulan data, maka peneliti tidak akan mendapatkan data yang memenuhi standar data yang ditetapkan. Dalam penelitian kualitatif pengumpulan data dilakukan pada natural setting (kondisi yang alamiah), sumber data primer dan tehnik pengumpulan data lebih banyak pada observasi berperan serta (participant observation), wawancara mendalam (in dept interview) dan dokumentasi. Maka pada penelitian tentang Upaya Meningkatkan Pendapatan Melalui Jual Beli Online dimasa Pandemi Covid-19 (Studi Kasus pada Toko Baju Afa Collection Kelurahan Sungai lokan Kecamatan Sadu) ini saya menggunakan tehnik Trangulasi yaitu gabungan dari Observasi, Wawancara dan Dokumentasi.

\section{Metode Pengumpulan Data Observasi}

Observasi adalah pengamatan yang dilakukan secara sengaja, sistematis mengenai fenomena sosial dengan gejala-gejala psikis untuk kemudian dilakukan pencatatan.Observasi disini diartikan secara langsung mengamati keadaan yang ada di Toko Baju Afa Collection.

\section{Wawancara}

Wawancara adalah percakapan dengan maksud tertentu, percakapan itu dilakukan oleh dua pihak yaitu pewawancara (interviewer) yang mengajukan pertanyaan kepada terwawancara (interviewe) yang memberikan jawaban atas pertanyaan itu.Oleh karena itu peneliti yang melakukan wawancara mempunyai tiga kewajiban yaitu:

${ }^{1}$ Boedi Abdullah dan Beni Ahmad Saebani. Metodologi Penelitian Ekonomi Islam,Cetakan, ke 1. (Bandung: CV Pustaka Setia, 2014), hlm. 49 
1) Memberitahu informan tentang hakikat penelitian dan pentingnya kerja sama mereka dengan penelitian;

2) Menghargai informan atas kerja samanya; dan

3) Memperoleh informasi dan data yang diinginkannya.

\section{Dokumentasi}

Dokumen sudah lama digunakan dalam penelitian sebagai sumber data karena dalam banyak hal dokumen sebagai sumber data dimanfaatkan untuk menguji, menafsirkan, bahkan untuk meramalkan. Sedangkan pada penelitian tentang Upaya Meningkatkan Pendapatan Melalui Jual Beli Online dimasa Pandemi Covid-19 (Studi Kasus pada Toko Baju Afa Collection Kelurahan Sungai lokan Kecamatan Sadu) ini dokumentasi yang digunakan adalah:

a) Dokumentasi Kegiatan Penelitian oleh Peneliti di Toko Baju Afa Collection kelurahan Sungai Lokan Kecamatan Sadu.

b) Dokumentasi Kegiatan-kegiatan yang mendukung penelitian pada Toko Baju Afa Collection Kelurahan Sungai Lokan Kecamatan Sadu.

c) Dokumen-dokumen pendukung lainnya yang terdapat pada Toko Baju Afa Collection Kelurahan Sungai Lokan Kecamatan Sadu.

\section{Prosedur Analisis Data}

Data mentah yang dikumpulkan oleh para petugas lapangan akan ada gunanya setelah dianalisis, analisis dalam penelitian merupakan bagian dalam proses penelitian yang sangat penting. Karena dengan analisa inilah data yang ada akan nampak manfaatnya terutama dalam memecahkan masalah penelitian dan mencapai tujuan akhir penelitian. Analisis data dalam penelitian Kualitatif dilakukan pada saat pengumpulan data berlangsung dan setelah selesai pengumpulan data dalam periode tertentu. Pada saat wawancara peneliti sudah melakukan analisis terhadap jawaban yang diwawancarai, bila jawaban yang diwawancai belum memuaskan maka peneliti akan melanjutkan pertanyaan lagi sampai tahap tertentu atau diperoleh data yang dianggap kridibel.

\section{Reduksi Data (Data Reduction)}

Data yang diperoleh dari lapangan jumlahnya cukup banyak, untuk itu maka perlu dicatat secara teliti dan rinci seperti telah dikemukakan, semakin lama peneliti kelapangan maka jumlah data akan semakin banyak, kompleks dan rumit. Untuk itu perlu dilakukan analisis data melalui reduksi data, merudiksi data berarti merangkum, memilih hal-hal yang pokok, dicari pola dan temanya. Dengan demikian data yang telah direduksi akan memberikan gambaran yang lebih jelas dan mempermudah peneliti untuk melakukan pengumpulan data selanjutnya(.P. Joko Subagyo, 2015)

\section{Penyajian Data (data display)}

Setelah data direduksi maka langkah selanjutnya adalah mendisplaykan data. Kalau dalam penelitian kualitatif penyajian data ini dapat dilakukan dalam bentuk tabel, grafik, phie chard, pictogram dan sejenisnya. Melalui penyajian data tersebut maka data terorganisasikan, tersusun dalam pola hubungan sehingga akan semakin mudah dipahami. Dalam penelitian kualitatif penyajian data bisa dilakukan dalam bentuk uraian singkat, bagan, hubungan antar 
kategori, flowchart dan sejenisnya. Dalam hal ini miles and huberman mengatakan yang sering digunakan untuk penyajian data dalam penelitian kualitatif adalah dengan teks yang bersifat naratif. Penyajian Data (data display).(P. Joko Subagyo, 2015)

\section{Conclusion Drawing/Verification}

Langkah ketiga dalam analisis data kualitatif menurut Miles and Huberman adalah penarikan kesimpulan dan verifikasi. Kesimpulan awal yang dikemukan masih bersifat sementara dan akan berubah bila tidak ditemukan bukti-bukti yang kuat yang mendukung pada tahap pengumpulan data berikutnya. Tetapi apabila kesimpulan yang dikemukakan pada tahap awal didukung oleh bukti-bukti yang vaid dan konsisten saat peneliti kembali kelapangan mengumpulkan data, maka kesimpulan yang dikemukakan adalah kesimpulan yang kridibel.(P. Joko Subagyo, 2015)

\section{Pemeriksaan Keabsahan Data}

Keabsahandatasudahsahjikamemilikiempatkriteriasesuai kriteriakeabsahan dataada empat macamyaitu:

- Kepercayaan (Kredibility)

- Keteralihan (Tranferability)

- Kebergantungan (Dependibility)

- Kepastian (Konfermability).(Lexi J. Moleong, 2014)

Triangulasi berarticara terbaikuntukmenghilangkanperbedaan-perbedaankonstruksikenyataan yangadadalamkontekssuatustudikewaktumenyimpulkandatatentang berbagai kejadian dan hubungan dari berbagai pandangan. Setelahpenelitimendapatkandata,baikituberupa data hasilwawancara,data dokumentasi, maupun dataobservasi, makaselanjutnyapeneliti melakukantriangulasi sumber, antaralain dengan cara:

1. Membandingkan data observasi yang didapatkan dengan wawancara pada informan

2. Membandingkan data wawancara antara informan satu dengan informan lainnya.

3. Membandingkan data wawancara dengan dokumentasi yang telah dikumpulkan

\section{HASIL PENELITIAN DAN PEMBAHASAN}

\section{Gambaran Umum Kelurahan Sungai Lokan KecamatanSadu Profil Toko Baju Dewi Busana}

Toko Afa Collection terletak di Jalan Nouncik RT. 002 RW. 01 Kelurahan Sungai Lokan Kecamatan Sadu Kabupaten Tanjung Jabung Timur Provinsi Jambi. Dengan luas Wilayah 95 km2. batas wilayah Sebelah utara berbatasan dengan Sungai Sadu, Sebelah Selatan berbatasan dengan Sungai Jambat dan Desa Simpang Jelita, Sebelah Timur berbatasan dengan Desa Simpang Jelita Kecamatan Nipah Panjang. jumlah Penduduk mencapai 3.578 Jiwa. Berdasarkan data Demografi Kelurahan Sungai lokan Kecamtan Sadu Jarak dari Pemerintahan ke Kecamatan 0,5 km2, Jarak dari Pusat Pemerintahan Ke Kabupaten Tanjung Jabung Timur $125 \mathrm{~km} 2$, jarak dari pusat pemerintahan ke ibu kota Provinsi Jambi 265 km2.

AFA Collection didirikan oleh Ibu Sulfa yang akrab disapa AFA pada tahun 2016. Selain Pendiri dari Afa Collection Ibu sulfa juga bekerja sebagai Pegawai Negeri Sipil dikantor 
kecamatan sadu bagian Kesejahteraan Sosial, Berawal dari coba-coba menjual berbagai busana, bermula dari menyalurkan hobby kemudian dikembangkang menjadi bisnis yang menghasilkan uang. Ide ini didapat dari artikel yang dibacanya yang memuat kalimat motivasi kerja yang paling menyenangkan adalah hobby yang dibayar, berdasarkan motivasi kerja inilah membuat ibu Sulfa berani membuka Toko Baju yang menjual berbagai macam Busana. Pada saat itu Toko Afa Collection mendapat sambutan baik dari masyarakat setempat dibuktikan dengan omset mencapai Kurang lebih Rp. 7.000 .000 per bulannya.

Toko Baju Dewi Afa Collection di bantu oleh 2 karyawan. buka pukul 07:30 hingga pukul 20:00, omset yang didapatkan Toko Baju Afa Collection rata-rata setiap bulannya yaitu Rp. 5.000.000 - Rp. 10.000.000.

\section{Temuan Hasil Penelitian}

Berdasarkan hasil penelitian yang dilakukan dilapangan tentang Upaya Meningkatkan Pendapatan melalui Jual Beli Online di masa Pandemi Covid-19 (Studi Kasus pada Toko Baju Afa Collection Kelurahan Sungai lokan Kecamatan Sadu) di Kelurahan Sungai Lokan Kecamatan Sadu Kabupaten Tanjung Jabung Timur ditemukan beberapa hal terkait tentang upaya yang dilakukan oleh Toko Baju Afa Collektion dalam meningkatkan pendapatan di tengah pandemi Covid-19 ini yaitu

\section{Upaya-upaya yang dilakukan}

Dampak pandemi Covid-19 terhadap perekonomian Indonesia cukup membuat resah masyarakat pada umumnya, karena banyak kegiatan perekonomian seperti ekspor dan infor tidak dapat dilakukan sebagaimana mestinya. Karena salah satu tindakan yang diambil pemerintah dunia untuk memutus mata rantai penyebarannya yaitu dengan memberlakukan system lock down atau karantina wilayah, hal inilah yang membuat kegiatan ekspor dan infor tersebut tidak dapat dilakukan. Akibat tidak terlaksananya kegiatan ekspor dan infor tersebut juga berdampak terhadap pendapatan masyarakat yang mengalami penurunan seperti para petani, nelayan dan para pelaku industri lainnya termasuk para pelaku usaha kecil dan menengah lainnya seperti Toko Baju Afa Collektion Kelurahan Sungai Lokan Kecamatan Sadu Kabupaten Tanjung Jabung Timur. Untuk tetap dapat bertahan dalam menjalankan usahanya di tengah pandemi Covid-19 ini maka Toko Baju Afa Collektion Kelurahan Sungai Lokan Kecamatan Sadu melakukan beberapa kegiatan yaitu dengan membuka pelayanan jual beli online sebagai solusi dalam mengatasi sepinya pasar karena pemberlakukan karantina wilayah, selanjutnya yaitu dengan membuka Reseller-reseller atau cabang dengan skala kecil dibeberapa wilayah kecamatan sadu untuk memperluas ruang pemasaran Toko Baju Afa Collektion dalam meningkatkan pendatapan ditengah pandemi Covid-19. Dengan Jual Beli Online dan Reseller ini diharapkan dapat menjadi solusi dalam memaksimalkan upaya Meningkatkan pendapatan, karena kedua hal tersebut dianggap sebagai solusi yang tepat sebagai bahan pertimbangan dalam menghadapi system karantina wilayah di Kecamatan Sadu Kabupaten Tanjung Jabung Timur. 


\section{Sistem yang digunakan dalam memaksimal Jual Beli Online}

Untuk memaksimalkan jual beli online Toko Baju Afa Collektion Kecamatan Sadu maka system yang digunakan adalah system COD dan Dropship, system COD merupakan pelayanan yang disediakan oleh toko baju Afa Collektion dalam memaksimalkan pelayanan kepada konsumen. dimana barang-barang yang dipesan konsumen dapat dibayar setelah barang dikirim dan diterima konsumen dirumah, system ini sebagai salah satu upaya dalam meningkatkan minat masyarakat terhadap toko baju Afa Collektion di Kelurahan Sungai Lokan Kecamatan Sadu. Sementara itu system dropship merupakan system yang digunakan dalam memaksimalkan jual beli online dengan membanyak jenis produk yang ditawarkan kepada konsumen, dengan banyaknya jenis produk yang ditawarkan diharapkan dapat memaksimalkan Meningkatkan penjualan guna meningkatkan pendapatan toko baju Afa Collektion Kelurahan Sungai Lokan Kecamatan Sadu.

\section{Pembahasan}

\section{Upaya yang dilakukan Toko Baju Afa Collektion dalam meningkatkan Pendapatan dimasa Pandemi Covid-19}

adapun upaya yang dilakukan dalam menjalankan usaha di masa pandemi Covid-19 ini adalah sebagai berikut:

a. Memanfaatkan Jual Beli Online

Memanfaatkan jual beli online untuk melakukan sebuah kegiatan usaha ataupun melakukan promosi dibidang usaha barang dan jasa merupakan langkah yang tepat, karena di era globalisasi ini handphone kini merupakan kebutuhan sekunder yang tidak dapat dipisahkan dalam kehidupan sehari-hari. karena teknologi kini banyak dimanfaatkan sebagai media informasi dan media hiburan dalam memenuhi kebutuhan dalam kehidupan sosial, terlebih kini media online telah berkembang menjadi salah satu sarana untuk menjalankan berbagai usaha oleh khalayak ramai. Hal inilah yang dimanfaatkan oleh toko baju Afa Collektion dalam berupaya mengatasi adanya kendala dalam menjalankan usaha di tengah pandemi Covid-19 ini

b. Membuka Reseller

Reseller merupakan orang-orang yang ingin membantu sebuah perusahaan atau badan usaha dalam melakukan penjualan produk yang sama pada suatu wilayah, dimana pada prakteknya reseller mendapatkan keuntungan sesuai dengan kemampuannya dalam menjalankan usaha. Karena reseller pada umumnya akan mendapatkan harga khusus dari perusahaan atau badan usaha agar dapat dijual kembali dan mendapatkan keuntungan, maka hal inilah yang dilakukan oleh toko baju Afa Collektion dalam meningkatkan pendapatan di masa pandemi Covid-19 ini. Dengan memanfaatkan reseller-reseller yang tersebar di Kecamatan Sadu maka diharapkan dapat menjadi solusi dalam meningkatkan pendapatan di tengah pendemi Covid-19 ini, karena dengan adanya reseller-reseller maka masyarakat yang berada pada suatu wilayah dapat melakukan pembelian barang tanpa harus menempuh jarak yang jauh. Adanya reseller-reseller ini merupakan terobosan yang dilakukan oleh ibu Sulfa selaku pemilik toko Afa Collektion dalam mengatasi masalah pemasaran pada masa pandemi Covid-19 ini, sebagaimana yang dikatakan Ayu Wandira yaitu: "Masalah Reseller-reseller itu memang benar adanya, hanya saja untuk saat ini 
jumlah reseller kita tidak banyak, hanya ada 7 orang yang tersebar di Kecamatan Sadu. Karena untuk menjadi reseller kita tidak cukup dengan modal jujur dan niat, soalnya kita tidak berani kasih barang kalau tidak ada jaminan. Maklum zaman sekarang ini semua butuh uang, nanti barang habis duitnya pun habis dan kami tidak dapat apa-apat. khawatirnya seperti itu". Ibu Noviyanti salah satu reseller toko baju Afa Collektion memberikan tanggapannya saat ditemui, menurutnya: "saya menjadi Reseller toko baju Afa Collektion ini belum ada 1 tahun, alasan saya menjadi reseller ini yang pastinya untuk mendapatkan tambahan penghasilan. Sebenarnya jadi reseller ini dulunya iseng aja lihat postingan bahwa mereka menawarkan masyarakat yang berkenan menjadi reseller gitu. Tapi Alhamdulillah hasilnya cukup baik karena barang-barang yang kurang laku bisa saya tukar kembali kesini, karena itu udah perjanjian kita dengan toko Afa Collektion. Untuk penukaran barang memang dibatasi hanya 1 kali, karena kita samasama pahamlah ya, kalo ditukar terus produk mereka habis untuk tukar-tukar aja".

\section{Sistem Jual Beli yang diterapkan oleh Toko Baju Afa Collektion dalam meningkatkan pendapatan dimasa pandemi Covid-19}

adapun sistem jual beli yang digunakan toko baju Afa Collektion yaitu:

a) Sistem COD

Sistem COD merupakan sebuah sistem yang dibuat dalam mengatasi rasa kurang percaya konsumen terhadap toko atau penjual dalam melakukan jual beli online, pada sistem COD pembeli akan membayar barang yang dibeli setelah barang diterima oleh pengirim barang atau pengusaha yang mengirim barang. Sistem COD ini hanya sebuah sistem yang memberi jaminan kepada konsumen bahwa barang yang dipesan benarbenar datang, bukan memastikan bahwa kualitas barang yang dipesan sesuai dengan yang diharapkan. Sistem inilah yang digunakan oleh toko baju Afa Collektion dalam meningkatkan penghasilan dimasa pandemic Covid-19 ini, pernyataan ini sesuai dengan pernyataan yang diungkapkan oleh ibu Sulfa yang mengatakan: "Kalau ditanya sistem yang kami gunakan yang pastinya ya sistem-sistem jual beli online pada umumnya, dimana ketika ada pemesanan barang maka kami akan mengirimkan barang sesuai dengan alamat dan tujuan. Hanya saja sistem pembayarannya saja yang berbedabeda karena kalau yang mesan barang itu alamatnya dapat kami jangkau maka pembayaran boleh setelah barang datang, tapi kalau konsumennya orang jauh maka kami minta pembayaran via transfer. Soalnya kalau mereka Cuma iseng-iseng kami jadi rugi, minimal rugi biaya pengiriman barang". Ibu Mutiara salah satu konsumen yang pernah menikmati pelayanan COD toko baju Afa Collektion memberikan tanggapannya tentang system COD ini, menurutnya: "iya benar saya sering pesan barang lewat facebook, kalau saya tertarik dengan barang yang diposting difacebook saya chat. Kalau bahannya cocok dan ukurannya ada saya pesan baru nanti mereka antar kerumah, tapi kebanyakan saya pesan seperti itu Cuma mesankan punya orang lain. Kaya punya Adik atau saudara-saudara dirumah, kalau untuk saya pribadi saya lebih suka beli itu lihat langsung barangnya. Harap maklum kalau online ini kita tau sama taulah ya". Jika dilihat dari prinsip bisnis manajemen Islam sistem COD sah untuk digunakan sebagai sistem jual beli dalam meningkatkan pendapatan, karena pada 
dasarnya kegiatan jual beli hendaknya dilakukan atas dasar suka sama suka tanpa adanya unsur pemaksaan oleh salah satu pihak.

b) Sistem Dropship

Sistem Dropship merupakan sistem jual beli yang memungkinkan semua orang untuk membuka sebuah usaha jual beli hanya dengan bermodalkan keberanian dan ketekunan dalam melakukan promosi, karena pada perakteknya sistem dropship merupakan sistem dimana penjual menawarkan produk-produk tanpa terlebih dahulu melakukan pembelian atau mennyiapkan barang yang akan dijual secara langsung. Sistem dropship ini banyak digunakan oleh masyarakat umum dalam melakukan usaha jual beli online dimana pelakunya hanya melakukan promosi barang milik perusahaan kepada khalayak ramai, jika barang yang dipromosikan mendapat respon oleh konsumen dengan melakukan pemesanan barulah barang tersebut dipesan oleh penjual untuk dijual kembali dengan harga yang sudah disepakati. Sistem dropship ini juga digunakan oleh toko baju Afa Collektion dalam meningkatkan pendapatan ditengah masa pandemi Covid-19 sebagai salah satu solusi karena adanya karantina wilayah yang diberlakukan pemerintah yang membuat pengusaha baju tidak dapat membeli pakaian untuk bahan diperjual belikan, pernyataan ini dikatakan langsung oleh ibu Sulfa pemilik toko Afa Collektion yang mengatakan: "Untuk melakukan pemesanan konsumen dapat berkunjung ke alamat Instagram atau facebook toko Afa Collektion, disana konsumen dapat memilih sendiri produk-produk yang kami tawarkan mulai dari Baju, Celana, Rok, Gamis, Jilbab, Tas dan berbagai jenis lainnya sebagai pilihan. Semua barang tersebut ada yang siap diambil ditoko tapi ada juga barang yang tidak ready. Kalau yang tidak ready itu karena barangnya kami pesan dulu, nanti setelah barang datang baru barangnya kami antarkan ke pelanggan yang melakukan pemesanan. Kalau masalah pembayaran gampang karena bisa bayar setelah barang datang". Nurlaili salah satu konsumen yang ditemui di Toko Afa Collektion memberikan pendapatnya saat ditemui, menurutnya: "saya pernah melakukan pemesanan di toko online afa collection, tapi sudah lama sekali. Menurut saya pelayanannya bagus dan malah kalau dari jenis produk di Instagram mereka jauh lebih banyak daripada barang yang ada di tokonya, hanya saja kalau di online itu terkadang barang harus pesan dulu tidak ready. Jadi harus nuggu barang datang baru kita bayar Manfaat dari system dropship yang disediakan oleh toko baju Afa Collektion ini juga dirasakan oleh Ibu Nidhaul, menurutnya: "Saya tidak langganan disini baru beberapa kali kesini untuk belanja sekalian ambil barang, kalau berbelanja ditoko onlinenya baru 2 kali masuk ini. beli di toko online mereka lumayan murah karena mungkin mereka ambil banyak sekali beli barang itu, memang kalau dibandingkan dengan kita pesan sendiri di Shoppy harga dari sini lumayan miring. Karena kan kalau pesan sendiri kita kena ongkir, apalagi kalau Cuma pesan 1 mahal lah makanya saya mesan barang lewat Afa Collektion ini. tapi terkadang beberapa barang sudah ready disini jadi kita bisa datang dan lihat kualitas dan ukuran". maka dari itu dapat disimpulkan bahwasannya sistem dropship yang digunakan oleh toko baju Afa Collektion dalam meningkatkan pendapatan di masa pandemi Covid-19 ini bisa dikatakan berhasil, karena masyarakat yang menjadi konsumen tidak hanya para pembeli namun juga orang-orang yang dikategorikan sebagai penjual. Hal itu 
tentunya membuat penambahan terhadap tingkat penjualan online toko baju Afa Collektion dalam meningkatkan pendapatan, karena pada umumnya pembelian barang yang dilakukan oleh para penjual lebih banyak dari pada pembelian barang yang dilakukan oleh pembeli.

\section{KESIMPULAN DAN SARAN}

\section{Kesimpulan}

Berdasarkan uraian hasil penelitian yang dilakukan penulis tentang Upaya Meningkatkan Pendapatan melalui Jual Beli Online di masa Pandemi Covid-19 (Studi Kasus pada Toko Baju Afa Collection Kelurahan Sungai lokan Kecamatan Sadu) maka dapat disimpulkan bahwa:

- Adapun yang melatar belakangi penelitian ini adanya permasalahan yang dihadapi oleh pedagang toko baju salah satunya Toko Affa Collektion dalam menjalankan usahanya di tengah pandemi covid-19, hal ini terjadi karena pasar menjadi sepi, sistem lockdown dan menurunnya pendapatan masyarakat sehingga memperkecil minat mereka untuk melakukan pembelian kebutuhan sekunder seperti pakaian. Maka untuk mengatasi kendala tersebut tentunya dibutuhkan upaya yang tepat agar Toko Affa Collektion dapat terus menjalankan usahanya, atas dasar itulah penulis tertarik untuk melakukan penelitian ini.

- Metode penelitian yang digunakan pada penelitian ini adalah metode kualitatif dengan tekhnik triangulasi, yaitu gabungan dari Observasi, Wawancara dan Dokumentasi. Yang menjadi sumber penelitian pada penelitian ini yaitu Tindakan, Kata-kata dan Dokumentasi yang ditemukan pada Toko Baju Affa Collektion Kelurahan Sungai Lokan Kecamatan Sadu.

- Upaya yang dilakukan oleh Toko Baju Afa Collection dalam meningkatkan pendapatan di masa Pandemi Covid-19 yaitu:

a. Memanfaatkan jual beli online sebagai sarana untuk menjalankan usaha di masa pandemic Covid-19 ini, dimana usaha dilakukan dengan menggunakan Aplikasiaplikasi sosial media, seperti Facebook sebagai sarana untuk melakukan promosi dan transaksi. Hal ini dilakukan karena melihat tingginya minat masyarakat terhadap jual beli online yang terkesan memberikan kemudahan dalam melakukan transaksi dan mencari referensi, oleh sebab itu dengan menggunakan jual beli online diharapkan dapat menjadi solusi untuk melakukan jual beli dimasa pandemi Covid-19 ini.

b. Membuka cabang reseller sebagai perpanjangan tangan untuk memperluas usaha diberbagai daerah terpencil serta sebagai salah satu peluang kerja bagi masyarakat yang ingin memulai sebuah usaha, reseller berfungsi untuk melakukan penjualan produk Afa Collection diberbagai daerah terpencil. dimana para reseller mendapatkan harga spesial agar mereka dapat kembali menjual barang dengan harga yang tidak terlalu tinggi namun tetap mendapatkan keuntungan, karena masyarakat yang menjadi reseller Toko Baju Afa Collection tidak mendapatkan gaji khusus atas jasa mereka yang telah membantu dalam memasarkan produk-produk Afa Collektion.

- Sistem Jual Beli Toko Baju Afa Collection dalam meningkatkan pendapatan di masa pandemic Covid-19 ini yaitu: 
a. Menerapkan sistem COD sebagai salah satu upaya dalam meningkatkan minat pelanggan yang pada umumnya memiki kekhawatiran terhadap adanya tindakan penipuan yang terjadi pada kegiatan jual beli online, namun yang mendapatkan fasilitas COD ini hanya konsumen yang berada pada daerah yang dapat dijangkau oleh Toko Baju Afa Collection dan bukam seluruh konsumen yang pada umumnya banyak berada pada area diluar Kelurahan Sungai Lokan Kecamatan Sadu.

b. Menerapkan sistem Dropship atau sistem menjual barang tanpa harus terlebih dahulu melakukan penyetokan terhadap barang yang ditawarkan, sistem ini digunakan sebagai salah satu solusi adanya kendalan Toko Baju Afa Collection dalam melakukan pembelian barang diluar kota serta sebagai upaya untuk meminimalisir modal dalam melakukan pembelian produk usaha. Sistem dropship menawarkan kesempatan penggunanya untuk memperbanyak jenis produk yang ditawarkan kepada konsumen, hal ini dikarekan sistem dropship merupakan kegiatan jual beli dengan menawarkan produk dari perusahaan orang lain sebagai produk yang kita sediakan.

\section{Saran}

Berdasarkan kesimpulan dari hasi penelitian tentang Upaya Meningkatkan Pendapatan melalui Jual Beli Online di masa Pandemi Covid-19 (Studi Kasus pada Toko Baju Afa Collection Kelurahan Sungai lokan Kecamatan Sadu) ini maka penulis menyarankan:

- Untuk menerapkan jual beli dengan sistem kredit kepada masyarakat karena salah satu dampak yang diakibatkan dari pandemi Covid-19 ini yaitu menurunnya tingkat perekonomian masyarakat karena adanya kebijakan pemerintah untuk melakukan karantina wilayah, maka dari itu dengan adanya sistem kredit maka akan mempermudah masyarakat untuk melakukan pembelian barang karena tidak perlu mengeluarkan uang dengan jumlah yang langsung besar karena bisa dengan sistem angsur.

- Menerapkan sistem gratis ongkir penulis rasa akan semakin memberikan daya tarik terhadap konsumen dalam melakukan jual beli online, karena terkadang yang menjadi bahan pertimbangan masyarakat dalam melakukan pembelian ditoko online adalah besarnya jumlah yang harus dikeluarkan untuk ongkos pengiriman barang.

\section{DAFTAR PUSTAKA}

Al-Qur'an danTerjemahnya (2016).Departemen Agama RI, CetakanPertama, Bandung, Rosdakarya

Akhmad Farroh Hasan (2018).Fiqh Muamalah dari Klasik hingga Kontemporer, Malang, Malikipress

Boedi Abdullah dan Beni Ahmad Saebani (2014). Metodologi Penelitian Ekonomi Islam,Cetakan Pertama. Bandung, CV Pustaka Setia

Disa Nusia Nisrina (2015). Jurnal Tinjauan Pustaka terhadap Jual Beli Online dan Relevansinya terhadap Undang-undang Perlindungan Konsumen, Makasar, Fakultas Syariah dan Hukum

Emzir (2016).Metodologi Penelitian Kualitatif Analisis Data, Cetakan, ke 5.Jakarta,PT Rajagrafindo Persada 
Lexi J. Moleong (2014).Metodologi Penelitian Kualitatif, Cetakan ke,3, Bandung, PT Remaja Rosdakarya

Michell Suharli (2006). Akutansi untuk Bisnis Jasa dan Dagang, Cetakan Pertama, Yogyakarta, Graha Ilmu

MK. Abdullah (2010). Kamus Bahasa Indonesia sesuai EYD, Cetakan Pertama, Bandung, Refika Aditama

Muhammad mahsun (2018).Pengukuran Kinerja Sektor Publik, cetakan ke 7. Yogyakarta, BPFE

Mohd.Nazir (2013).Metode Penelitian, Cetakan Kedelapan, Bogor, Ghalia Indonesia

P. Joko Subagyo (2015). Metode Penelitian dalam Teori dan Praktik, Cetakan ke 7, Jakarta, PT Rineka Cipta

Rholen Bayu Saputra (2014).Jurnal Profile Pedagang Kaki Lima yang berjualan di Badan Jalan, Universitas Riau

Sadono Sukirno (2016). Makro Ekonomi Teori Pengantar, Cetakan Pertama, Jakarta, PT Raja Grafindo Persada

Wawancara dengan Ibu Sulfa Pemilik Toko Baju Afa Collection 27 Mei 2021

Wawancara dengan Ibu Nur Arafah Karyawati Toko Baju Afa Collection 27 Mei 2021

Wawancara dengan Ibu Ayu Wandira Adik Pemilik Toko Baju Afa Collection 27 Mei 2021

Wawancara dengan Ibu Siti Hadrawati Karyawati Toko Baju Afa Collection 29 Mei 2021

Wawancara dengan Ibu Sri Maharani Konsumen Toko Baju Afa Collection 05 Juni 2021

Wawancara dengan Ibu Nidhaul Konsumen Toko Baju Afa Collection 05 Juni 2021 